\title{
Gagal Jantung Kongestif dan Fibrilasi Atrium: Apa Terapi Terbaik?
}

\author{
Yoga Yuniadi
}

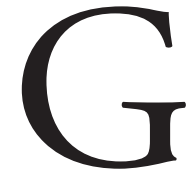
agal jantung bukan menurun bahkan meningkat prevalensinya. ${ }^{1}$ Terapi sindrom koroner akut yang lebih baik dan makin banyaknya populasi manula ditengarai sebagai penyebab peningkatan tersebut. Gagal jantung sistolik menimbulkan peningkatan tekanan akhir diastolik ventrikel kiri yang akhirnya akan meningkatkan pula tekanan atrium kiri sehingga terjadi remodeling atrium yang kemudian menyebabkan terjadinya fibrilasi atrium (FA). Sebaliknya FA dengan respon ventrikel yang cepat dan tidak terkontrol juga akan menyebabkan remodeling ventrikel yang berujung pada gagal jantung. Selain itu FA juga meningkat pada manula, sejalan dengan peningkatan kejadian gagal jantung.

Kejadian duo gagal jantung dan FA bervariasi mulai dari $6 \%$ pada pasien dengan simtom minimal atau asimtomatik hingga mencapai $35 \%$ pada pasien dengan New York Heart Association (NYHA) kelas II-IV. ${ }^{2-5}$ Keberadaan duo itu boleh jadi karena keduanya memiliki faktor risiko dan mekanisme yang sama. Faktor risiko itu meliputi hipertensi, diabetes melitus, penyakit jantung iskemik dan penyakit katup jantung. ${ }^{6}$

Duo gagal jantung dan FA memiliki prognosis yang lebih jelek yaitu mortalitas yang lebih tinggi dibandingkan masing-masing kondisi. Menurut

\section{Alamat Korespondensi}

Dr. dr. Yoga Yuniadi, SpJP. Divisi Aritmia, Departemen Kardiologi dan Kedokteran Vaskular, FKUI dan Pusat Jantung Nasional Harapan Kita, Jakarta. E-mail: yogay136@gmail.com
Studi Framingham, pasien gagal jantung kongestif yang kemudian mengalami FA memiliki rasio hazard kematian 1.6 pada laki-laki dan 2.7 pada perempuan dalam pengamatan selama 4.2 tahun. Begitu juga bila pasien FA yang kemudian mengalami gagal jantung kongestif mempunyai rasio hazard kematian 2.7 pada laki-laki dan 3.1 pada perempuan dalam pengamatan selama 5.6 tahun. $^{7}$

Terjadi diskusi panjang tentang terapi apa yang terbaik bagi pasien dengan duo gagal jantung dan FA. Tidak seperti pasien gagal jantung yang memiliki irama sinus, pada pasien FA terdapat paling tidak dua persoalan tambahan, yaitu: (1) hilangnya atrial kick yang dapat mengurangi curah jantung hingga 30\%, dan (2) risiko laju jantung yang cepat yang lebih sulit dikelola dan mencetuskan gagal jantung akut.

\section{Digoksin}

Digoksin suatu obat inotropik positif yang sudah sangat lama dikenal. Sempitnya jendela terapeutik dan terjadinya peningkatan konsumsi oksigen miokardium pada pemakaian digoksin menyebabkan indikasi pemakaiannya terbatas. Panduan terapi gagal jantung meletakkan digoksin dalam indikasi kelas IIa dengan tingkat bukti $\mathrm{B}$ atau $\mathrm{C}$ untuk mengurangi hospitalisasi gagal jantung pada pasien gagal jantung dengan fraksi ejeksi yang menurun. ${ }^{8,9}$ Keuntungan hospitalisasi ini diperoleh baik pada pasien dengan irama sinus maupun FA, iskemik maupun non iskemik, dan pasien dalam terapi inhibitor enzyme konversi angiotensin (EKA) 
maupun tidak. Digoksin tidak memiliki pengaruh terhadap penurunan mortalitas. Digoksin biasanya baru diberikan bila pasien masih ada gejala walaupun sudah dalam terapi optimal sesuai dengan panduan. ${ }^{8}$

Suatu metaanalisis ${ }^{10}$ terhadap 19 studi observasional untuk mengetahui efek digoksin terhadap mortalitas segala sebab dengan melibatkan 300.000 pasien FA dan/atau gagal jantung. Metaanalisis ini menunjukkan bahwa terapi digoksin berhubungan dengan peningkatan risiko mortalitas terutama pada pasien FA. Tiga dari 19 uji klinis dalam metaanalisis tersebut melibatkan 117.434 subjek dengan gagal jantung dan FA. ${ }^{11-13}$ Sumber data dan analisis pada ketiga studi tersebut identik dan ditampilkan secara terpisah untuk subset FA dan gagal jantung (Gambar 1). Pada kelompok FA digoksin berhubungan dengan peningkatan risiko kematian (HR 1.28, 95\% CI, 1.12 to $1.46, \mathrm{P}, 0.01$ ) sedangkan pada analisis subset gagal jantung kongestif tidak terdapat perbedaan mortalitas antara pemakai dengan bukan pemakai digoksin (HR $1.05,95 \% \mathrm{CI}, 0.91$ to $1.20, \mathrm{P} 1 / 40.52$ ).

Metaanalisis lain terhadap 11 studi observasional mencoba meneliti hubungan antara digoksin dengan mortalitas segala sebab pada pasien FA. Didapatkan digoksin berhubungan dengan peningkatan risiko mortalitas sebesar 21\% (HR 1.21, 95\% CI 1.12 to 1.30). Berbeda dengan metaanalisis sebelumnya, pada studi ini ketika dilakukan analisis subgroup pada pasien dengan atau tanpa gagal jantung didapatkan digoksin tetap berhubungan dengan peningkatan mortalitas pada kedua subgroup tersebut. ${ }^{14}$
Kedua metaanalisis di atas mengubah paradigma lama tentang manfaat digoksin khususnya pada pasien FA. Sebagai klinisi kedua data di atas harus membuat kita lebih hati-hati dan selektif dalam pemakaian digoksin. Sementara belum ada suatu penelitian acak terkontrol, untuk meninggalkan sepenuhnya penggunaan digoksin sebagai kendali laju pada pasien FA hanya dengan berdasarkan metaanalisis dari studi observasional.

\section{Penghambat Beta}

Penggunaa obat penghambat beta untuk pasien gagal jantung dan FA masih menjadi pilihan untuk mengendalikan laju jantung, khususnya pada gagal jantung dengan fraksi ejeksi yang menurun. Obat penghambat beta lebih disukai dari pada digoksin untuk kendali laju karena lebih baik mengontrol laju jantung saat latihan. Dalam panduan tatalaksana gagal jantung ESC, obat penghambat beta menjadi pilihan pertama untuk gagal jantung dengan disfungsi ventrikel kiri dan FA dengan indikasi kelas I dan tingkat bukti A. ${ }^{15}$

Berbeda dengan panduan di atas, sebuah metaanalisis mengenai efek obat penghambat beta pada pasien gagal jantung dan FA. Empat studi acak terkontrol yang melibatkan jumlah total subjek 1667 dengan gagal jantung dengan penurunan ejeksi fraksi dan FA menunjukkan bahwa luaran obat penghambat beta tidak sebaik pada pasien dengan irama sinus.

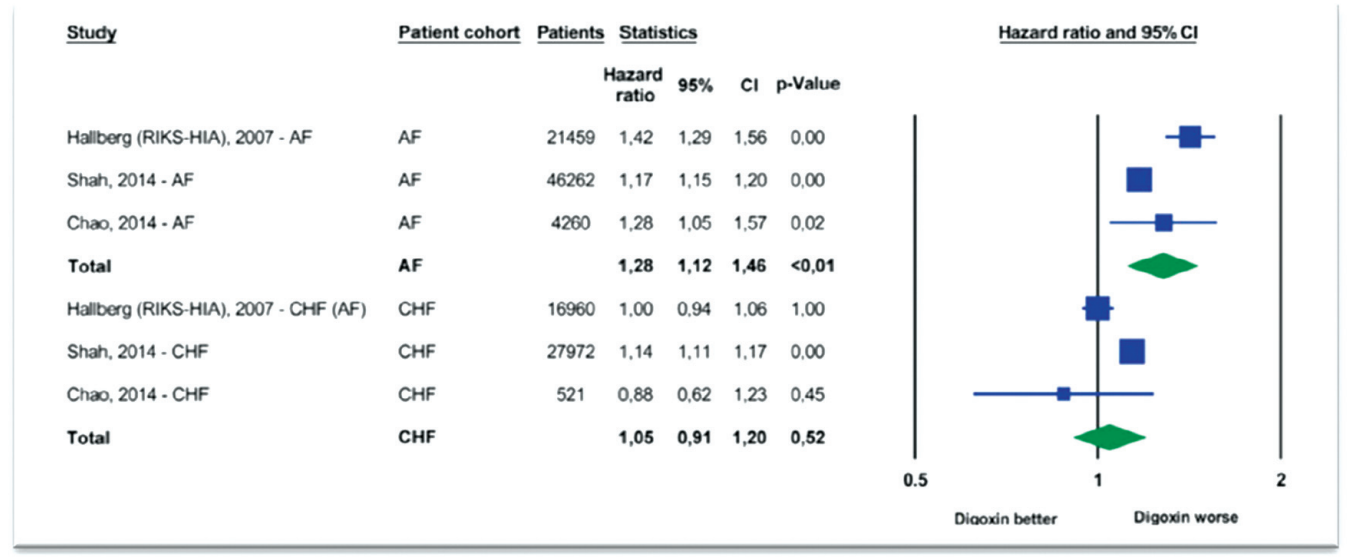

Gambar 1. Grafik forest plot tiga studi pada populasi gagal jantung dan FA. Analisis dilakukan terpisah pada subset FA dan subset gagal jantung. Dikutip dari kepustakaan no 10. 
Obat penghambat beta tidak menurunkan hospitalisasi (OR: 1.11 [95\% CI: 0.85 to 1.47 ]; $\mathrm{p}=0.44$ ) maupun mortalitas (OR: 0.86 [95\% CI: 0.66 to 1.13 ]; $\mathrm{p}=$ $0.28) .{ }^{16}$

Metaanalisis lain yang dipublikasikan di Lancet tahun 2013 terhadap 10 trial acak terkontrol mengenai perbandingan obat penghambat beta dengan placebo pada pasien gagal jantung. Adanya irama FA atau sinus diidentifikasi dari EKG awal. Sebanyak 18254 subjek yang terdiri dari $13946(76 \%)$ pasien dengan irama sinus dan 3066 (17\%) pasien dengan irama FA. Obat penghambat beta menurunkan mortalitas segala sebab pada pasien dengan irama sinus (HR $0.73,95 \% \mathrm{CI}$ $0.67-0.80 ; \mathrm{p}<0.001)$ tetapi tidak pada irama FA (HR $0.97,95 \%$ CI 0.83-1.14; $\mathrm{p}=0.73$ ). Hal yang sama juga terjadi pada tingkat hospitalisasi.17 (Gambar 3)

Kedua metaanalisis di atas seyogyanya memberikan suatu pandangan baru dalam hal pemakaian obat penghambat beta untuk gagal jantung dengan fraksi ejeksi yang menurun dan FA. Rekomendasi pemakaian

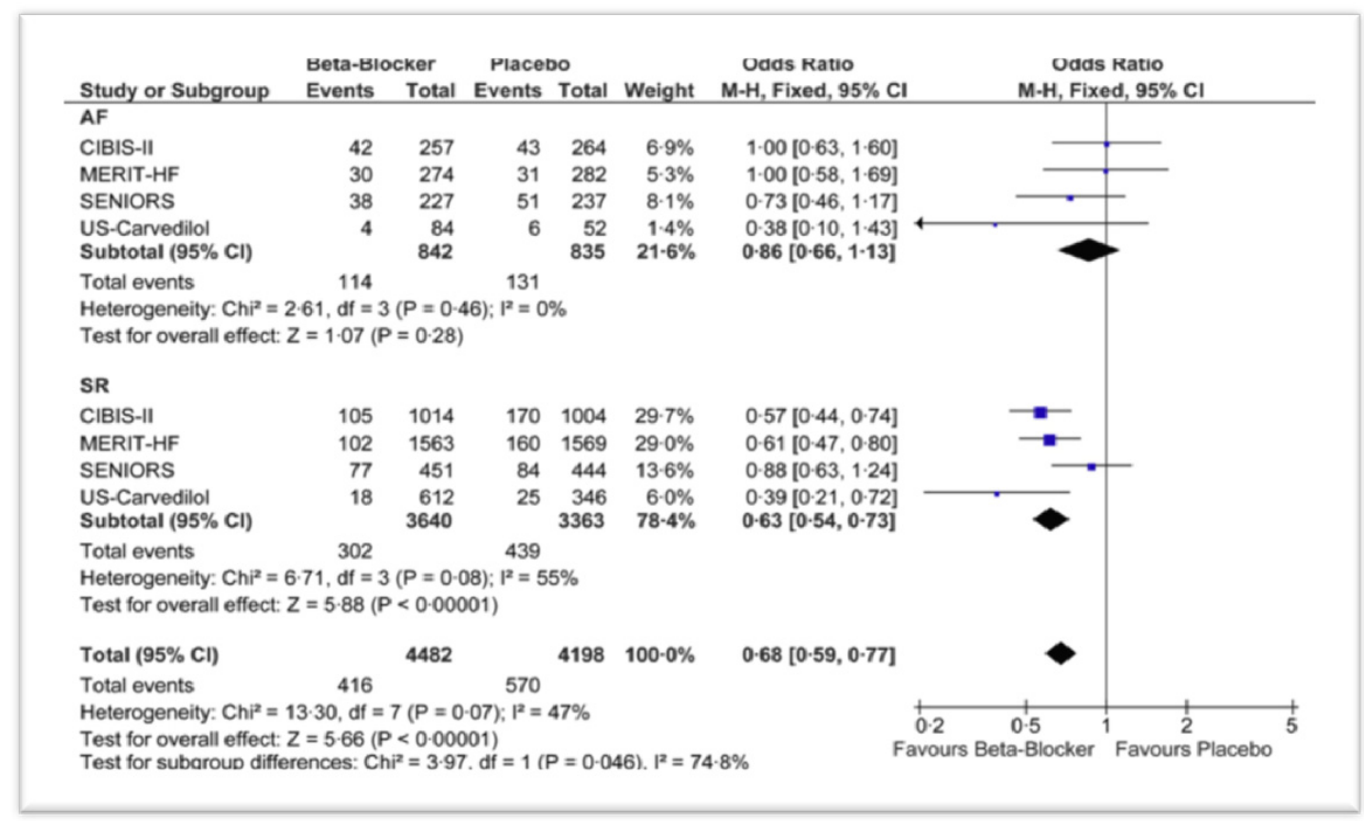

Gambar 2. Efek obat penghambat beta terhadap mortalitas segala sebab pada pasien gagal jantung dan FA. Dikutip dari kepustakaan no. 16
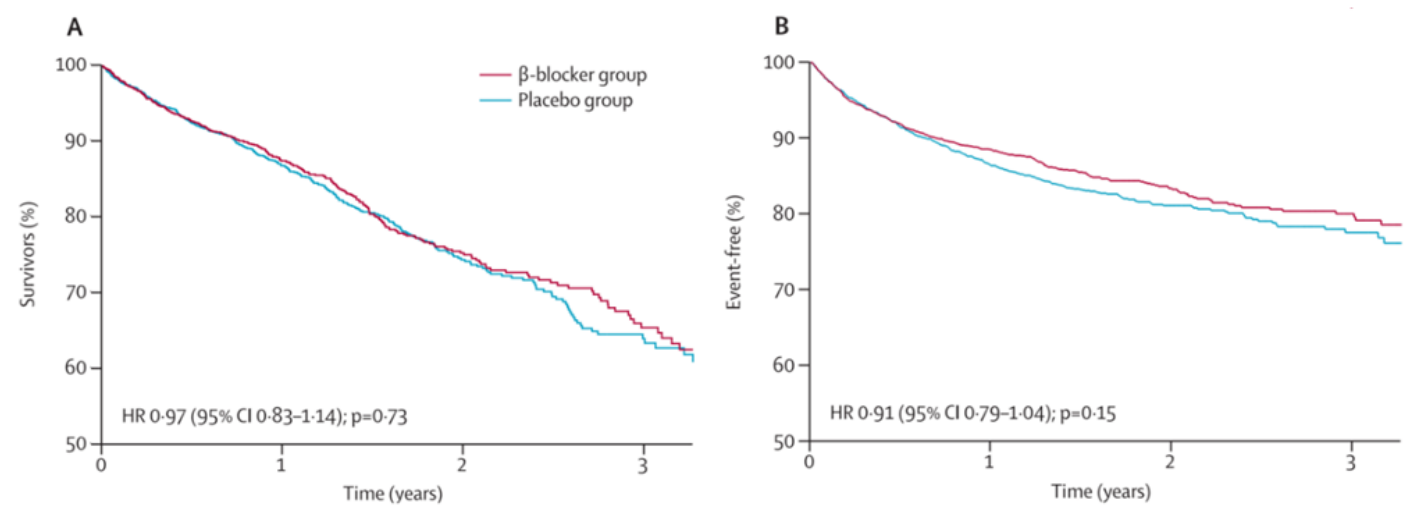

Gambar 3. Kurva Kaplan-Meier efek obat penghambat beta pada pasien gagal jantung dan irama FA baik pada mortalias (A) maupun hospitalisasi (B). Tampak tidak ada perbedaan manfaat antara obat penghambat beta dibandingkan placebo. Dikutip dari kepustakaan no. 17 
obat penghambat beta untuk duo gagal jantung dan FA perlu disikapi dengan sangat hati-hati. Pemakaian obat penghambat beta sebagai kendali laju FA harus dilakukan secara selektif dan pemantauan yang ketat.

Kegagalan digoksin dan obat penghambat beta untuk terapi duo gagal jantung dan FA cukup menyulitkan dalam tatalaksana keadaan tersebut karena obat kendali laju lain yang tersisa adalah penghambat kanal kalsium yang justru tidak dapat digunakan pada keadaan gagal jantung dengan fraksi ejeksi yang menurun. Barangkali ini saatnya kita membuka peluang lebih besar untuk tatalaksana FA secara invasif dengan ablasi radiofrekuensi. Studi CAMTAF (Catheter Ablation Versus Medical Treatment of Atrial Fibrillation in Heart Failure) $)^{18}$ memperlihatkan bahwa ablasi radiofrekuensi efektif mengembalikan irama sinus pada pasien FA dan gagal jantung yang menghasilkan perbaikan fungsi ventrikel kiri, kapasitas fungsional dan gejala-gejala gagal jantung dibandingkan dengan terapi kendali laju.

\section{Daftar Pustaka}

1. Bleumink GS, Knetsch AM, Sturkenboom MC, Straus SM, Hofman A, Deckers JW, Witteman JC and Stricker BH. Quantifying the heart failure epidemic: prevalence, incidence rate, lifetime risk and prognosis of heart failure The Rotterdam Study. Eur Heart J. 2004;25:1614-9.

2. Corell P, Gustafsson F, Schou M, Markenvard J, Nielsen T and Hildebrandt P. Prevalence and prognostic significance of atrial fibrillation in outpatients with heart failure due to left ventricular systolic dysfunction. Eur J Heart Fail. 2007;9:258-65.

3. De Ferrari GM, Klersy C, Ferrero P, Fantoni C, Salerno-Uriarte D, Manca L, Devecchi P, Molon G, Revera M, Curnis A, Sarzi Braga S, Accardi F and Salerno-Uriarte JA. Atrial fibrillation in heart failure patients: prevalence in daily practice and effect on the severity of symptoms. Data from the ALPHA study registry. Eur J Heart Fail. 2007;9:502-9.

4. Dries DL, Exner DV, Gersh BJ, Domanski MJ, Waclawiw MA and Stevenson LW. Atrial fibrillation is associated with an increased risk for mortality and heart failure progression in patients with asymptomatic and symptomatic left ventricular systolic dysfunction: a retrospective analysis of the SOLVD trials. Studies of Left Ventricular Dysfunction. J Am Coll Cardiol. 1998;32:695-703.

5. van Veldhuisen DJ, Aass H, El Allaf D, Dunselman PH, Gullestad L, Halinen M, Kjekshus J, Ohlsson L, Wedel H and
Wikstrand J. Presence and development of atrial fibrillation in chronic heart failure. Experiences from the MERIT-HF Study. Eur J Heart Fail. 2006;8:539-46.

6. Ho KK, Pinsky JL, Kannel WB and Levy D. The epidemiology of heart failure: the Framingham Study. J Am Coll Cardiol. 1993;22:6A-13A.

7. Wang TJ, Larson MG, Levy D, Vasan RS, Leip EP, Wolf PA, D’Agostino RB, Murabito JM, Kannel WB and Benjamin EJ. Temporal relations of atrial fibrillation and congestive heart failure and their joint influence on mortality: the Framingham Heart Study. Circulation. 2003;107:2920-5.

8. Yancy CW, Jessup M, Bozkurt B, Butler J, Casey DE, Jr., Drazner MH, Fonarow GC, Geraci SA, Horwich T, Januzzi JL, Johnson MR, Kasper EK, Levy WC, Masoudi FA, McBride PE, McMurray JJ, Mitchell JE, Peterson PN, Riegel B, Sam F, Stevenson LW, Tang WH, Tsai EJ and Wilkoff BL. 2013 ACCF/AHA guideline for the management of heart failure: executive summary: a report of the American College of Cardiology Foundation/American Heart Association Task Force on practice guidelines. Circulation. 2013;128:1810-52.

9. Camm AJ, Lip GY, De Caterina R, Savelieva I, Atar D, Hohnloser SH, Hindricks G, Kirchhof P, Guidelines-CPG ESCCfP and Document R. 2012 focused update of the ESC Guidelines for the management of atrial fibrillation: an update of the 2010 ESC Guidelines for the management of atrial fibrillation-developed with the special contribution of the European Heart Rhythm Association. Europace. 2012;14:1385-413.

10. Vamos M, Erath JW and Hohnloser SH. Digoxin-associated mortality: a systematic review and meta-analysis of the literature. Eur Heart J. 2015;36:1831-8.

11. Hallberg P, Lindback J, Lindahl B, Stenestrand U, Melhus H and group R-H. Digoxin and mortality in atrial fibrillation: a prospective cohort study. Eur J Clin Pharmacol. 2007;63:95971.

12. Shah M, Avgil Tsadok M, Jackevicius CA, Essebag V, Behlouli $\mathrm{H}$ and Pilote L. Relation of digoxin use in atrial fibrillation and the risk of all-cause mortality in patients $>/=65$ years of age with versus without heart failure. Am J Cardiol. 2014;114:401-6.

13. Chao TF, Liu CJ, Chen SJ, Wang KL, Lin YJ, Chang SL, Lo LW, Hu YF, Tuan TC, Chen TJ, Chiang CE and Chen SA. Does digoxin increase the risk of ischemic stroke and mortality in atrial fibrillation? A nationwide population-based cohort study. Can J Cardiol. 2014;30:1190-5.

14. Ouyang AJ, Lv YN, Zhong HL, Wen JH, Wei XH, Peng HW, Zhou J and Liu LL. Meta-analysis of digoxin use and risk of mortality in patients with atrial fibrillation. Am J Cardiol. 2015;115:901-6.

15. McMurray JJ, Adamopoulos S, Anker SD, Auricchio A, Bohm M, Dickstein K, Falk V, Filippatos G, Fonseca C, GomezSanchez MA, Jaarsma T, Kober L, Lip GY, Maggioni AP, Park- 
homenko A, Pieske BM, Popescu BA, Ronnevik PK, Rutten FH, Schwitter J, Seferovic P, Stepinska J, Trindade PT, Voors AA, Zannad F, Zeiher A and Guidelines ESCCfP. ESC Guidelines for the diagnosis and treatment of acute and chronic heart failure 2012: The Task Force for the Diagnosis and Treatment of Acute and Chronic Heart Failure 2012 of the European Society of Cardiology. Developed in collaboration with the Heart Failure Association (HFA) of the ESC. Eur Heart J. 2012;33:1787847.

16. Rienstra M, Damman K, Mulder BA, Van Gelder IC, McMurray $\mathrm{JJ}$ and Van Veldhuisen DJ. Beta-blockers and outcome in heart failure and atrial fibrillation: a meta-analysis. JACC Heart Fail. 2013;1:21-8.
17. Kotecha D, Holmes J, Krum H, Altman DG, Manzano L, Cleland JG, Lip GY, Coats AJ, Andersson B, Kirchhof P, von Lueder TG, Wedel H, Rosano G, Shibata MC, Rigby A, Flather MD and Beta-Blockers in Heart Failure Collaborative G. Efficacy of beta blockers in patients with heart failure plus atrial fibrillation: an individual-patient data meta-analysis. Lancet. 2014;384:2235-43.

18. Hunter RJ, Berriman TJ, Diab I, Kamdar R, Richmond L, Baker V, Goromonzi F, Sawhney V, Duncan E, Page SP, Ullah W, Unsworth B, Mayet J, Dhinoja M, Earley MJ, Sporton S and Schilling RJ. A randomized controlled trial of catheter ablation versus medical treatment of atrial fibrillation in heart failure (the CAMTAF trial). Circ Arrhythm Electrophysiol. 2014;7:31-8. 